ENTREPRENEURSHIP AND SUSTAINABILITY ISSUES

ISSN 2345-0282 (online) http://jssidoi.org/jesi/

2020 Volume 7 Number 4 (June)

http://doi.org/10.9770/jesi.2020.7.4(20)
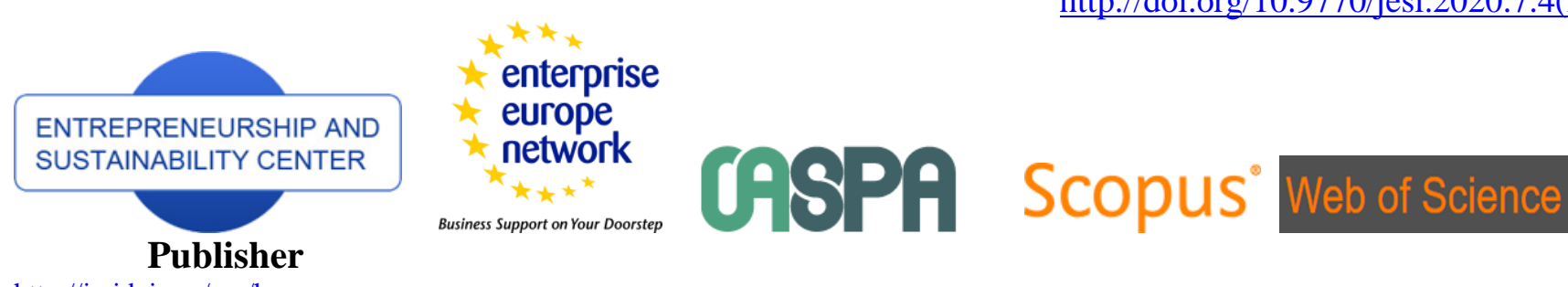

$\underline{\text { http://jssidoi.org/esc/home }}$

Business Support on Your Doorstep

I) Clarivate

Analytics

\title{
CHALLENGES OF OUTSOURCING ACCOUNTING IN LATVIA AND LITHUANIA
}

\author{
Ivita Faituša ${ }^{1}$, Rasa Subačienė ${ }^{2}$, Aida Mačerinskienė ${ }^{3}$ \\ ${ }^{1}$ University of Latvia, Raina boulv.19, Riga, LV-1050, Republic of Latvia \\ ${ }^{2,3}$ Vilnius University, Sauletekio al. 9, Vilnius, LT-10222, Republic of Lithuania \\ E-mails. ${ }^{1}$ ivita.faitusa@lu.lv ; ${ }^{2}$ rasa.subaciene@evaf.vu.lt $;{ }^{3}$ aida.macerinskiene@evaf.vu.lt
}

Received 15 November 2019; accepted 15 March 2020; published 30 June 2020

\begin{abstract}
Accounting provides around $80 \%$ of information of any type and sort of activity of legal entity and significantly influences the decisions of accounting information users. The accountant profession, which had faced many challenges over the past few years, now is proving to be no exception. The article looks at both theory and practice and attempts to determine and understand problematic issues about outsourcing accounting challenges. The purpose of the research is to evaluate outsourcing accounting challenges in Latvia and Lithuania. The research deployed the survey, the inductive and deductive methods, the methods of systematisation, comparison and a summary of information. Research object - companies providing outsourcing accounting services in the Republic of Latvia and the Republic of Lithuania. From the results of the research the authors have come to the following conclusions: the biggest challenges for accounting outsourcing companies of both countries are keeping up with new regulations and standards and technology developments. Both countries have quite a similar view on challenges of accounting outsourcing companies, however, Lithuanian respondents provided opinion on more significant challenges such as attracting new customers, differentiating from competition and experiencing pressure to lower fees, as Latvian respondents - emphasized challenge of keeping up with new regulations and standards.
\end{abstract}

Keywords: accounting; outsourcing accounting

Reference to this paper should be made as follows: Faituša, I., Subačienè, R., Mačerinskienè, A. 2020. Challenges of outsourcing accounting in Latvia and Lithuania. Entrepreneurship and Sustainability Issues, 7(4), 2883-2896. http://doi.org/10.9770/jesi.2020.7.4(20)

JEL Classifications: M41

\section{Introduction}

In Latvia and Lithuania accounting outsourcing does not have rich experience as first companies started to provide accounting services after both countries regained their independence in 1990. However, in the 30 years the companies achieved a good reputation, national companies had developed to an international level, international companies expanded their activity, and recently the companies have qualified staff and provide efficient services at both national and international level. Although as any other companies, they face challenges, which may influence not only the companies, which provide accounting services, but buyers of accounting services as well as all other accounting information users. 


\section{ENTREPRENEURSHIP AND SUSTAINABILITY ISSUES}

ISSN 2345-0282 (online) http://jssidoi.org/jesi/

2020 Volume 7 Number 4 (June)

http://doi.org/10.9770/jesi.2020.7.4(20)

Research results of various authors (Bartkus etc., 2009; Kutuzov, Kotsiuba, 2015; Bagieńska, 2016; Liakhovych, 2017; Mwangi, Mutiso, Mungai, 2018 and others) confirm the usefulness of accounting outsourcing. However, numerous researches in the area of accounting profession and provision of accounting services show that the companies and accountants face such challenges as accountant's ability to adapt to the rapid pace of change or talent, client satisfaction or trust, automation, the impact of new technologies, Brexit, and so on. (Hood, 2018, MindSpace, 2018, IFAC 2019). That served as a background for the evaluation of the challenges of accounting outsourcing in Latvia and Lithuania.

The purpose of the research is to evaluate accounting outsourcing challenges in Latvia and Lithuania. The research deployed the survey, the inductive and deductive methods, the methods of systematisation, comparison and a summary of information. Research object - companies providing outsourcing accounting services in the Republic of Latvia (here and after - Latvia) and the Republic of Lithuania (here and after - Lithuania).

\section{Research methodology}

Figure 1 presents the methodology of the research, which was carried out in several phases to evaluate outsourcing accounting challenges in Latvia and Lithuania. First stage includes investigation of outsourcing accounting worldwide and in selected countries. Latvia and Lithuania were chosen for the research as countries, which have similar economic, political and cultural background as well as had started their development at the same conditions and are developing at quite similar level: GDP per capita makes around half of the EU 28 indicator in both countries (Main GDP aggregates per capita, 2020), growth of real GDP is at the same level and during 3 last years made around 0,9 percentage change (Gross domestic product, 2020), employment rate had reached around 77 percent in 2018 (Employment rate, 2020), the level of minimum wage make around 430 Eur (in Lithuania official value of minimum wage is estimated 607 Eur for 2020 year, although the value was recalculated by eliminating result of 2019 tax reform for comparison of indicators) (Trading Economy, 2020), etc. In both countries actively perform the Big4 international companies (Ernst \& Young (EY), (PricewaterhouseCoopers (PwC), Klynveld Peat Marwick Goerdeler (KPMG), Deloitte Touche Tohmatsu Limited (Deloitte)) as well as other national/ international legal entities, which provide accounting services.

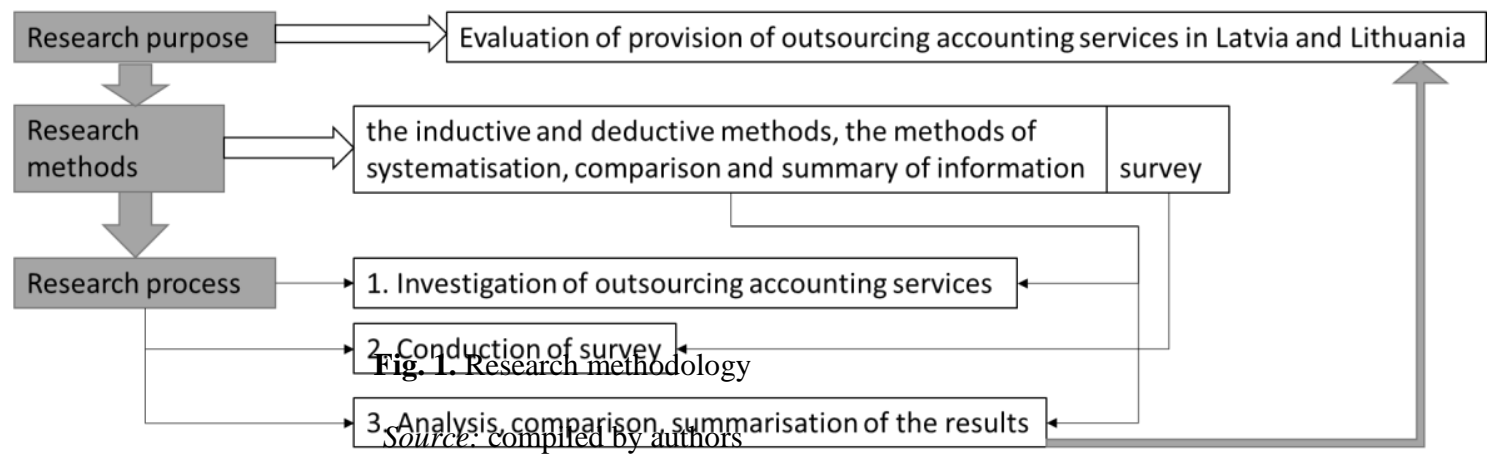

Second stage of the research was dedicated to the preparation and conduction of the survey. The survey was conducted in November, 2019 in Lithuania and Latvia. The questionnaire was prepared for executives of accounting outsourcing companies, heads of the accounting departments. The structure of questionnaire is presented in Table 1. Different types of questions where provided in the questionnaire: multiple choice (MCHQ), Likert scale (LS), open ended questions (OQ). The questionnaire was situated on public on-line system. 81 responses from Lithuanian outsourcing accounting companies and 87 - from Latvian outsourcing accounting 
ENTREPRENEURSHIP AND SUSTAINABILITY ISSUES

ISSN 2345-0282 (online) http://jssidoi.org/jesi/

2020 Volume 7 Number 4 (June)

http://doi.org/10.9770/jesi.2020.7.4(20)

companies were received. Results included answers from the Big4 companies and make around $30 \%$ of outsourcing accounting market.

Table 1. Structure of the questionnaire

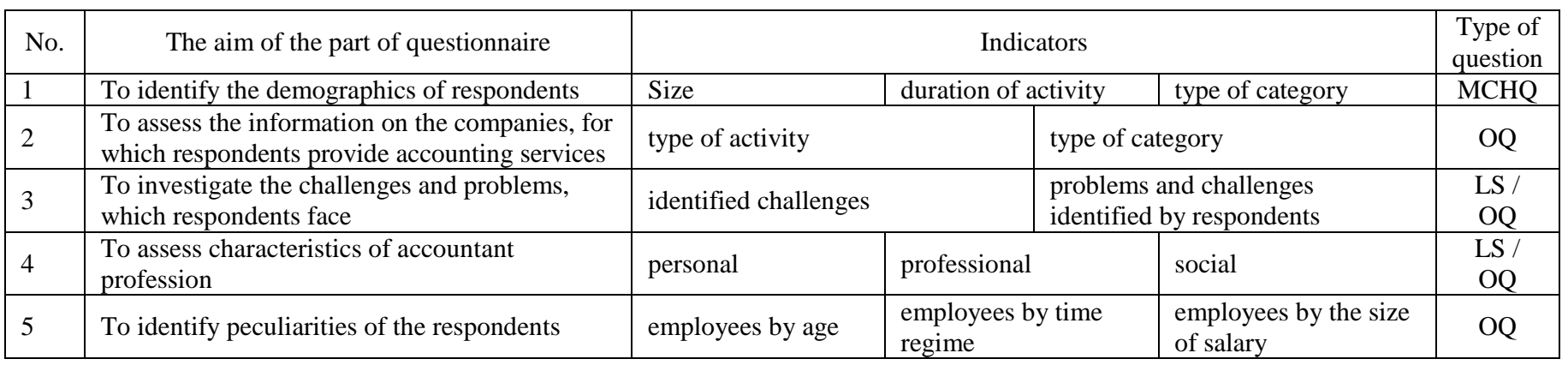

Source: compiled by authors

For evaluation of challenges and problems, which companies face by providing accounting services, Likert scale of 5 points questions were formulated as well as open ended questions. Likert scale of 5 points and open ended questions were used for evaluating characteristics of accountant profession, too. Characteristics for accountant's profession were distinguished according to proposition of Mackevičius, Subačienè (2016). Authors presented 3 groups of characteristics: 1) personal, 2) professional and 3) social. Personal group consist of such characteristics as: accuracy; analytical skills and logical thinking; integrity; ability to resist workspace routine; ability to learn; responsibility; determination; ability to resist stress and pressure; independence; ability to independently and continuously learn; ability to gather, process, analyse and critically evaluate the data; creativity; management ability; risk taking; decision-making. Professional group of characteristics consists of such person's abilities: to record economic transaction to accounting documents and registers; to prepare financial statements; to prepare different statements of different accounting types and spheres; to form financial accounting policy; to form tax accounting policy; to form management accounting policy; to form information system of the company; to plan, analyse and evaluate company's performance; to conduct researches and present analysis results; to support internal control system; to present analytical results, to identify problems and propose alternatives to problem solving to make decisions; to be interested in innovations and changes in regulation. Social group of characteristics includes such abilities: to communicate with colleagues and persons from other institutions; to cooperate with colleagues and persons from other institutions; to work in a team. Respondents in addition were asked to indicate other characteristics, which might be important for accountant as open ended questions. Open ended questions were formulated for evaluation of such indicators of respondents as employees by age; employees by time regime, employees by the size of salary. The third stage includes analysis of the survey's results in each country as well as comparison and summarisation of the results.

\section{The overview of outsourcing accounting}

Development of every business process may persist or arise contradiction between the need of improvement and the limited company resources. The experience of many companies around the world shows that in such cases, it is the best not to try to improve business processes, but to borrow the process from companies in the industry and take advantage of it. Outsourcing external resources helps the company focus on its core business. The freed up of internal resources can be directed for improvement of the efficiency of the organization, focusing only on the specialization of the company and realization of its' main tasks. (Bartkus etc., 2009). So, one of the possibilities for the business is purchase accounting services. The main advantages of accounting outsourcing may be defined such as savings on accounting staff salaries; cost savings on organization of working places in accounting, 


\section{ENTREPRENEURSHIP AND SUSTAINABILITY ISSUES}

ISSN 2345-0282 (online) http://jssidoi.org/jesi/

2020 Volume 7 Number 4 (June)

http://doi.org/10.9770/jesi.2020.7.4(20)

department software, training staff; access to skilled counseling; improvement of the quality and reliability of the functions performed by the outsourcer (Kutuzov, Kotsiuba, 2015). Research results of G. M. Mwangi, A. Mutiso, D. Mungai (2018) show, that accounting outsourcing has a positive influence on financial performance of small and medium-sized enterprises (SMEs), purchase of accounting services enhance relevancy, reliability, and improvement in financial performance of small and medium enterprises. In addition, authors of the study conclude that the size of the enterprise as an indicator of accounting outsourcing does not influence financial performance of the SMEs (Mwangi, Mutiso, Mungai, 2018). The same opinion on the usefulness of accounting outsourcing provide A. Bagieńska (2016). The author under the research results concludes that the most important factors influencing the entrepreneur's cooperation with the accounting office are: high quality of services resulting from the competence of the employees of the office, the range of services offered by the company, advising on finance management, correctness of tax accounting, the possibility of using additional services (Bagieńska, 2016).

In general, the main reasons why companies outsource their services are to ensure a high level of productivity and to offer maximum quality to their own customers. The area of outsourced service is vast, including but not limited to business process outsourcing, human resources services, and information technology outsourcing. Some of the most outsourced global services are financial accounting services, generating much of Business Process Outsourcing revenue. The largest global payers in this area are Deloitte, PricewaterhouseCoopers, Ernst\&Young, and KPMG constituting The Big4 offering services such as accounting, auditing, corporate finance or insurance services (Popovici, Moraru, 2018). Like other forms of outsourcing, finance and accounting outsourcing has evolved significantly in recent years (Krell, 2011).

The main element of the process of provision of accounting services is employees of the companies. And employees as members of accountant profession will face significant changes in the next three decades. They as well as professional organizations, their members, and educational institutions, will have to respond. The three changes, namely, evolving smart and digital technology, continued globalization of reporting / disclosure standards, and new forms of regulation, are also significant challenges for the profession (Islam, 2017). For now, the Framework for International Education Standards for Professional Accountants and Aspiring Professional Accountants (2015) defines such requirements for the accountant profession: preparing, analyzing, and reporting relevant and faithfully represented financial and nonfinancial information; partnering in decision-making and in formulating and implementing organisational strategies; developing and examining relevant tax information (Bruna I. et al, 2017).

In Latvia, there are no mandatory requirements regarding education for a practicing accountant. Public authorities of the Republic of Latvia should genuinely look at the accountancy profession to determine the level of qualification and experience required to establish and ensure that skilled accountants manage a company's financial statements (Millere, Faitusa et.al. 2018). Amendments to the Law on Accounting are planned with licensing rules for outsourcing accountants in 2020. Requirements for a professional accountant as well as regulations for outsourcing accounting companies and outsourcing accountants are defined in the Law on Accounting (2019) in Lithuania. According to the Law on Accounting (2019) professional accountant is a member of professional organization of auditors and / or accountants of Lithuania or any other European Union Member State, which belongs to the International Federation of Accountants. Accountants have to meet special requirements and to pass special exams for achievement of the status of professional accountant. Accounting outsourcing companies or outsourcing accountants have to be insured by civil insurance.

It may be generalised that there are specific rules for outsourcing accountants just in Norway: external accountants must be authorized by the Financial Supervisory Authority of Norway (Finanstilsynet) and shall conduct their client's duties according to the accounting and bookkeeping legislation. External accountants shall do its business by sound accounting practice. External accountants shall prepare reports and information to their 
clients that they must provide by law or regulation. These include annual accounts, value-added tax reports, reports for tax and national insurance, etc. (European Commission, 2019).

The International Federation of Accountants Global SMP Survey 2016 investigated practitioners from small and medium-sized practices across the globe on their challenges as well as how various environmental factors may affect them over the next five years (IFAC, 2017) (see Fig. 2, Fig. 3).

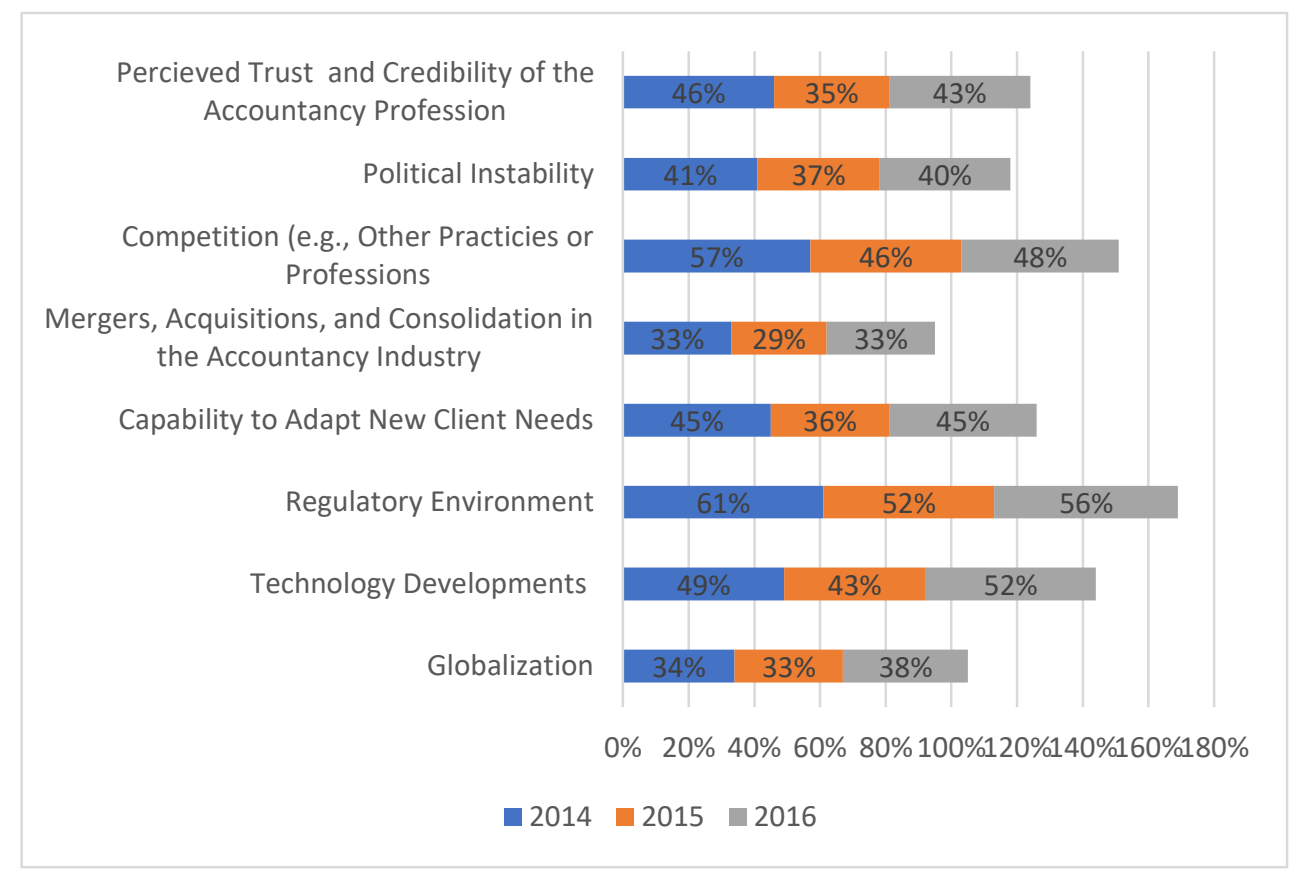

Fig. 2. Factors impacting accounting practises over next five years- comparison of 2014, 2015 and 2016 survey results

Source: compiled by authors, based on IFAC, 2017

The Figure 2 shows how respondents rated eight factors to indicate the degree to which they believe each element can impact their practice over the next five years. Consistent with 2014 and 2015, the regulatory environment continued to be viewed as the most impactful with $56 \%$ of respondents anticipating that it will have a high or very high impact. Technology developments at 52\% up from $43 \%$ in 2015 were viewed as having the next highest potential impact on SMEs. The percentage of respondents that rated the anticipated implications of capability to adapt to new client needs as high or very high (45\% up from 36\% in 2015), and perceived trust and credibility of the profession (43\%, up from 35\% in 2015) increased substantially in comparison to 2015. For all four of the environmental factors noted, sensitivity to the factors increased in 2016, falling more in line with 2014 survey results (IFAC, 2017). 
ENTREPRENEURSHIP AND SUSTAINABILITY ISSUES

ISSN 2345-0282 (online) http://jssidoi.org/jesi/

2020 Volume 7 Number 4 (June)

http://doi.org/10.9770/jesi.2020.7.4(20)

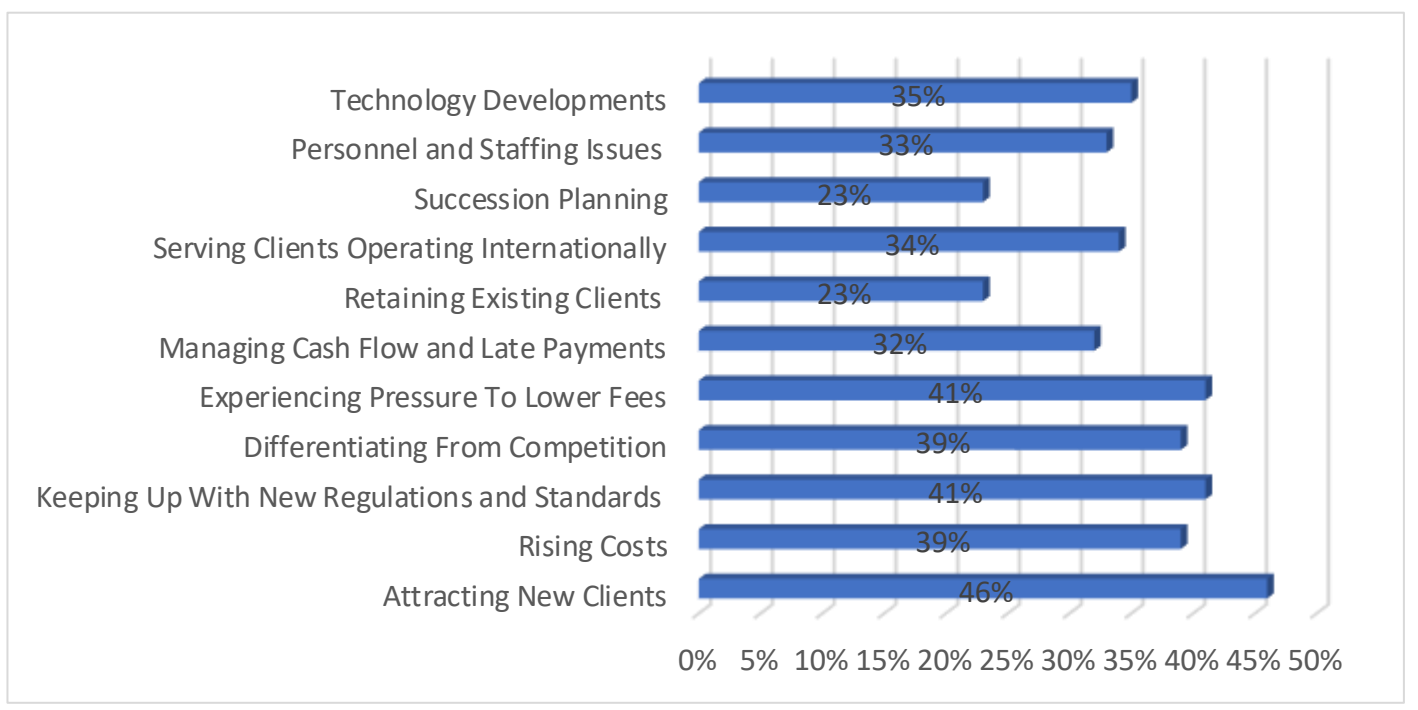

Fig. 3. Impact of 11 Challenges on small and medium-sized practices across the globe $(2014,2015,2016$ sum of high and very high challenge)

Source: compiled by authors, based on IFAC, 2017

Analysis of data in Figure 3 results shows that certain challenges were viewed as more pressing with greater than $40 \%$ of respondents rating the following as high and very high challenge: attracting new clients, keeping up with new regulations and standards and experiencing pressure to lower fees (IFAC, 2017). The main elements of analysed survey were used for the evaluation of challenges of accounting outsourcing companies in Latvia and Lithuania.

\section{Evaluation of the results of the research}

The outsourcing accounting takes a rather significant place in both countries. In the last few years, more and more micro and small companies use outsourcing accounting instead of an employees' hiring. Research results show that most of the companies have one owner, who is self-employed accountant, ( $24 \%$ in Lithuania (LT), 28 $\%$ in Latvia (LV) and 2-5 owners with staff (39\% LT, $43 \% \mathrm{LV})$, although the number of such companies in Latvia is by almost 8 percentage points higher, what indicates that in Lithuania share capital of companies, who provide accounting services, is more differentiated. The Figure 4 presents age and category of the outsourcing companies in both countries. 


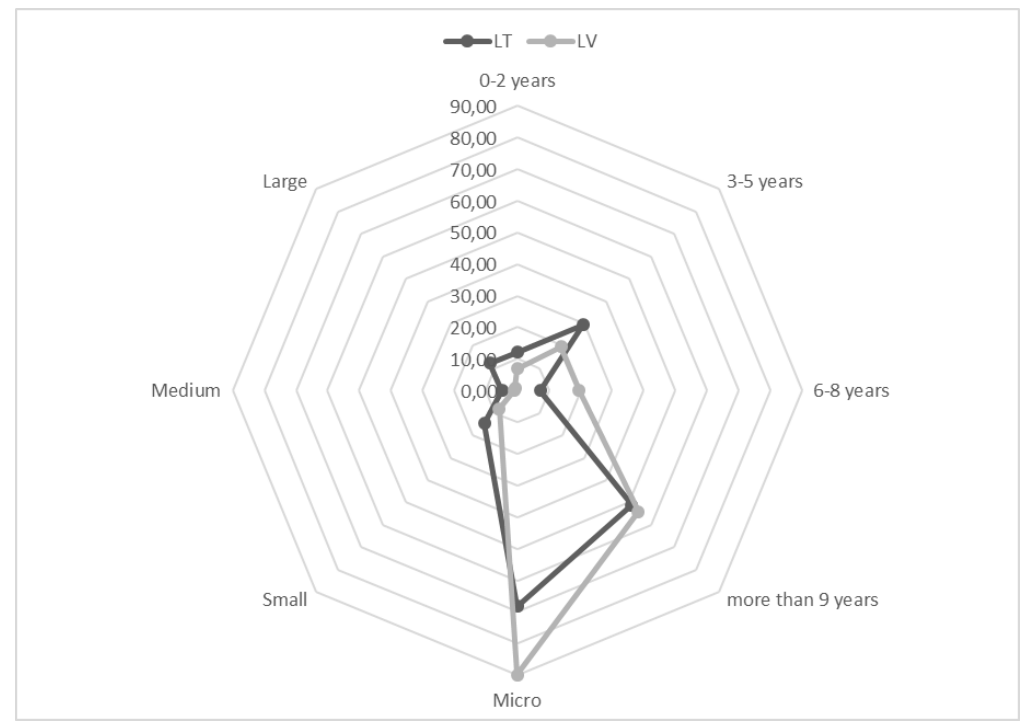

Fig. 4. The age and category of companies, $\%$

Source: compiled by authors

More than half companies have performed for more than 9 years in both countries as well as most of the companies are micro (68\% LT; $90 \% \mathrm{LV})$ as in both countries micro companies make the biggest part of all categories. At this aspect Lithuania may be characterized by wider diversity of categories in the sphere. Although the biggest part of companies has quite long period of performance, young companies, who operate till 5 years, make $42 \%$ in Lithuania and $27 \%$ in Latvia.

Types of activity and categories of companies, who use accounting services are presented in Figure 5.

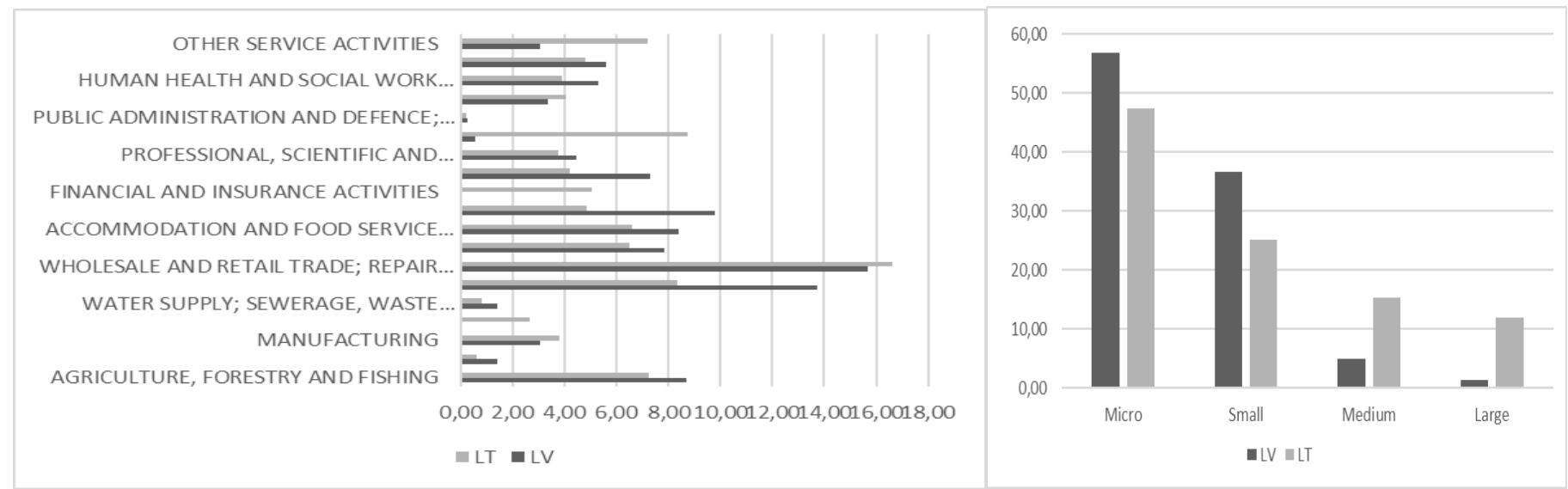

Fig. 5. 1ypes of activity and categories of companies, who use accountıng services, $\%$

Source: compiled by authors

Research results show, that types of activity of companies, who purchase accounting services are sufficiently similar in both countries and do not differ more than 5 percentage points except of administrative and support service activities, which the number of Latvian companies exceed by more than 8 percentage points. Different situation shows analysis of categories of companies, who use accounting services: Lithuanian companies 


\section{ENTREPRENEURSHIP AND SUSTAINABILITY ISSUES}

ISSN 2345-0282 (online) http://jssidoi.org/jesi/

2020 Volume 7 Number 4 (June)

http://doi.org/10.9770/jesi.2020.7.4(20)

provided accounting services for smaller companies (almost $94 \%$ of companies are micro and small companies) than Latvian (more than $27 \%$ are medium and large companies).

Figure 6 presents the respondents' opinion of challenges, which face companies providing accounting services. Research results show, that companies face more challenges by attracting new customers in Lithuania than in Latvia: more than $50 \%$ of respondents in Latvia strongly disagree or disagree, that they face such a challenge, as in Lithuania this part makes only slightly more than $34 \%$. The same part of respondents agrees or strongly agrees on the statement in Lithuania as in Latvia the number makes - less than $21 \%$. Almost the same part of respondents (around $32 \%$ ) in Lithuania neither agree, nor disagree with the statement, in Latvia - more than 24 $\%$. Respondents in both countries don't think, that rising costs are a significant challenge, their opinions distributed almost in equal parts: around one third of respondents strongly disagree or disagree with the statement as well as neither agree nor disagree and strongly agree or agree. Although there are differences in opinion on the statement, that keeping up with new regulations and standards is a challenge, as bigger part of Latvian companies by $25 \%$ perceive the challenge while more than $26 \%$ of Lithuanian respondents strongly disagree or disagree with the statement (Latvian - almost $5 \%$ ). It should be mentioned, that only one of the Big4 companies strongly disagreed with the statement. Although some of micro and small younger Lithuanian companies expressed the opinion, that in Lithuania legislation is edited too often and usually important amendments are enforced from the beginning of new year as the amendments are published at the end of the current year (last week or so of December), so companies have only one or two weeks to prepare for the changes. Inefficient work of information systems of social insurance fund and state tax inspectorate were also mentioned as problems. In Latvia the main question for outsourcing accountants today is the development of the internal control system in accordance with Law on the Prevention of Money Laundering and Terrorism and Proliferation Financing (Saeima, 2008). Lithuanian respondents faced the same problem recently, but still see the procedures as bureaucratic and time consuming. Accountants expressed the opinion, that this process and preparation of the procedures is a very bureaucratic process. Planning, lack of staff, the changes in legislation, competition were also mentioned as challenges for outsourcing accountants in Latvia.
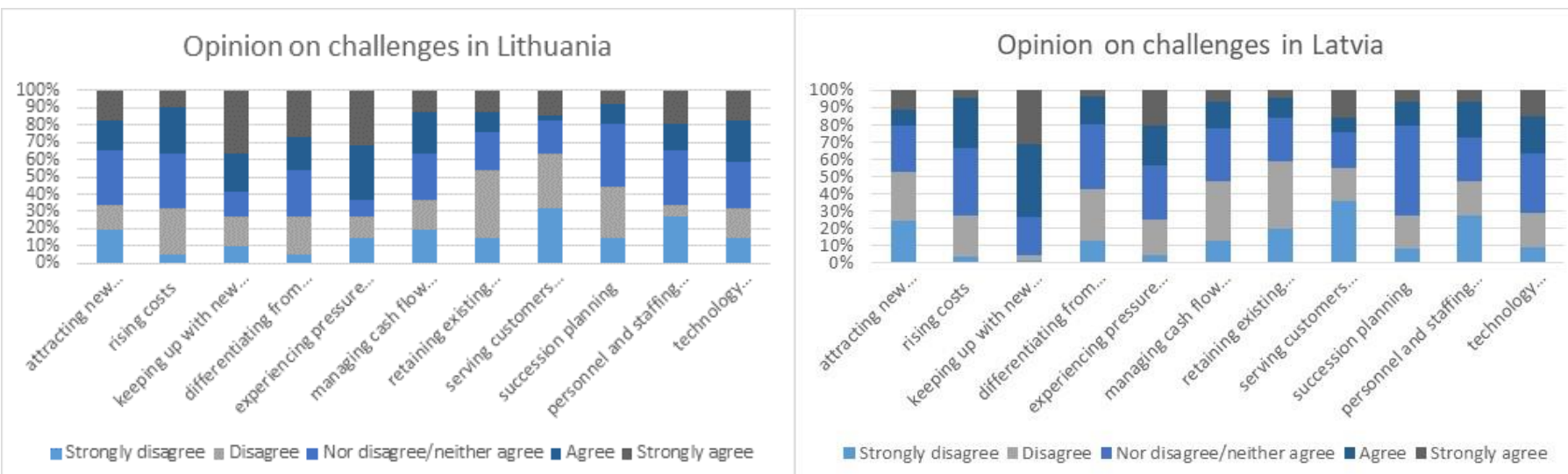

Fig. 6. Analysis of challenges in Lithuania and Latvia, \%

Source: compiled by authors

It may be stated, that differentiating from competition is significantly more of a challenge for Lithuanian outsourcing accounting companies, as more than $46 \%$ of respondents strongly agree or agree with the statement (including two the Big4 companies); in Latvia this number adds up to almost $20 \%$, as well as almost $38 \%$ nor agree, nor disagree and $42 \%$ strongly disagree or disagree with the statement (in Lithuania, both of these numbers make $27 \%$ accordingly). Evaluation of results of the statement of 'experiencing pressure to lower fees' appears in a rather similar situation: by $45 \%$ of Lithuanian companies perceive this challenge as more significant 
ENTREPRENEURSHIP AND SUSTAINABILITY ISSUES

ISSN 2345-0282 (online) http://jssidoi.org/jesi/

2020 Volume 7 Number 4 (June)

http://doi.org/10.9770/jesi.2020.7.4(20)

and almost $10 \%$ nor agree, nor disagree with the statement (in Latvia - 31\%). Around one fourth of respondents in both countries - strongly disagree or disagree with the challenge. It should be mentioned that respondents provided the opinion, that they face the challenges with reasoning of their work and its' importance to the clients as well as financial literacy of clients and receipt of accounting documents on time. Almost half of Latvian companies don't perceive challenge in managing cash flow and late payments and one third has neutral opinion. In Lithuania - the same part of respondents $(37 \%)$ strongly disagree or disagree or strongly agree or agree with the statement. Respondents of both countries don't face a challenge of retaining existing customers: $54 \%$ Lithuanian respondents and $59 \%$ of Latvian respondents strongly disagree or disagree with the statement, have neutral opinion accordingly $-22 \%$ and $25 \%$. The same opinion is on serving customers operating internationally: $63 \%$ of Lithuanian respondents and $55 \%$ of Latvian respondents strongly disagree or disagree with the statement, in both countries $20 \%$ of respondents have a neutral position. Besides, respondents of micro and small companies commented that the internal control system is very important for the company as well as qualification differentiation in rather small companies for responding the challenges in a proper way.

However, a different situation in analysed countries shows analysis of challenge of succession planning: although in both countries $20 \%$ of respondents strongly agree or agree with the challenge, but only $28 \%$ of Latvian respondents strongly disagree or disagree with the challenge. In Lithuania this part makes $44 \%$, neutral opinion is accordingly $52 \%(\mathrm{LV})$ and $37 \%$ (LT). More personnel and staffing issues face Lithuanian companies: $34 \%$ of respondents strongly agree or agree with the statement, in Latvia it makes $28 \%$, and $47 \%$ of respondents strongly disagree or disagree with the statement (in Lithuania - $34 \%$ ). The analysis' results may be supported by comments of respondents, which refer to the problems of lack of qualified staff in Lithuania, it cannot be considered that the problems are not for Latvian outsourcing accounting companies. Both countries have rather similar view on challenge of technology developments. Neutral opinion of the challenge of technological developments in Latvia have $34 \%$ of respondents, in Lithuania - $27 \%$. Around one third of respondents in both countries strongly disagree or disagree with the statement.

Characteristics of accountant profession of personal sphere are presented in Figure 7. Research results show a rather interesting situation: respondents from both countries agree with around 5 percentage points difference, that the accountant profession has to have such characteristics as: accuracy, analytical skills and logical thinking, integrity, ability to resist work routine, ability to resist stress and pressure, ability to learn, responsibility.

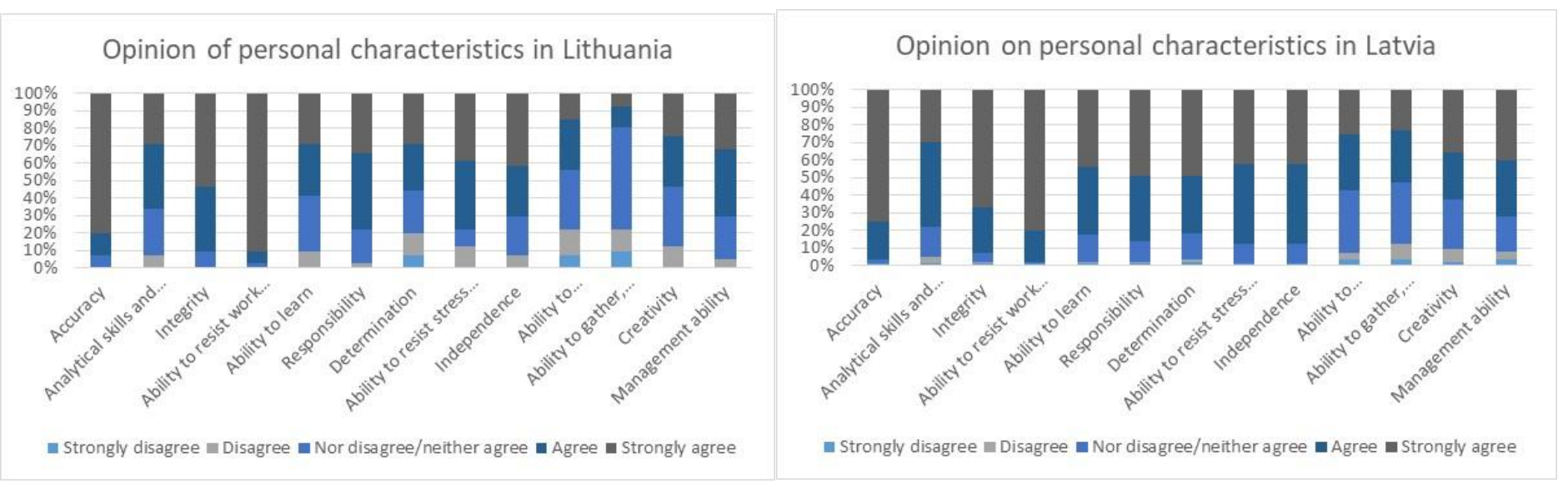

Fig. 7. Characteristics of accountant profession of personal sphere in Lithuania and Latvia, \%

Source: compiled by authors 
ENTREPRENEURSHIP AND SUSTAINABILITY ISSUES

ISSN 2345-0282 (online) http://jssidoi.org/jesi/

2020 Volume 7 Number 4 (June)

http://doi.org/10.9770/jesi.2020.7.4(20)

Although $70 \%$ and more of respondents of both countries agree or strongly agree with the characteristics of personal sphere as ability to independently and continuously learn, ability to gather, process, analyse and critically evaluate the data, and decision-making, however, $8 \%$ of respondents in Lithuania and almost $4 \%$ respondents in Latvia, strongly disagree or disagree with such qualities of accountant profession or almost $19 \%$ of Lithuanian respondents and $15 \%$ of Latvian respondents have neutral position. Differences between opinions lay on such abilities as independence (more than $3 \%$ of Latvian respondents strongly disagree or disagree with the characteristic, almost $15 \%$ have neutral opinion and Lithuanian respondents accordingly - almost $20 \%$ and more than $24 \%$ ), creativity (almost $7 \%$ of Latvian respondents strongly disagree or disagree with the characteristic, almost $36 \%$ have neutral opinion and Lithuanian respondents accordingly - almost $22 \%$ and more than $34 \%$ ), management ability (almost $13 \%$ of Latvian respondents strongly disagree or disagree with the characteristic, almost $35 \%$ have neutral opinion and Lithuanian respondents accordingly - almost $22 \%$ and almost $59 \%$ ). Such results may be evaluated contradictory (especially for characteristic of creativity, which is most valued characteristic of any profession recently) as well as the fact that opinion was provided by different types of companies' categories: micro, medium and large, although the Big4 companies value the characteristics of independence and creativity. Around $62 \%$ of Latvian respondents and $54 \%$ of Lithuanian respondents strongly agree or agree, that risk taking is an important characteristic for the accountant profession.

Analysis of professional characteristics of accountant profession shows (see Fig. 8), that more than $80 \%$ of respondents of both countries agree only on ability to record economic transaction to accounting documents and registers, and ability to prepare financial statements. $83-87 \%$ of Latvian respondents agree or strongly agree, that accountant profession have to have such abilities as ability to form financial accounting policy, ability to form tax accounting policy and be interested in innovations as only $46-59 \%$ of Lithuanian respondents have the same opinion.

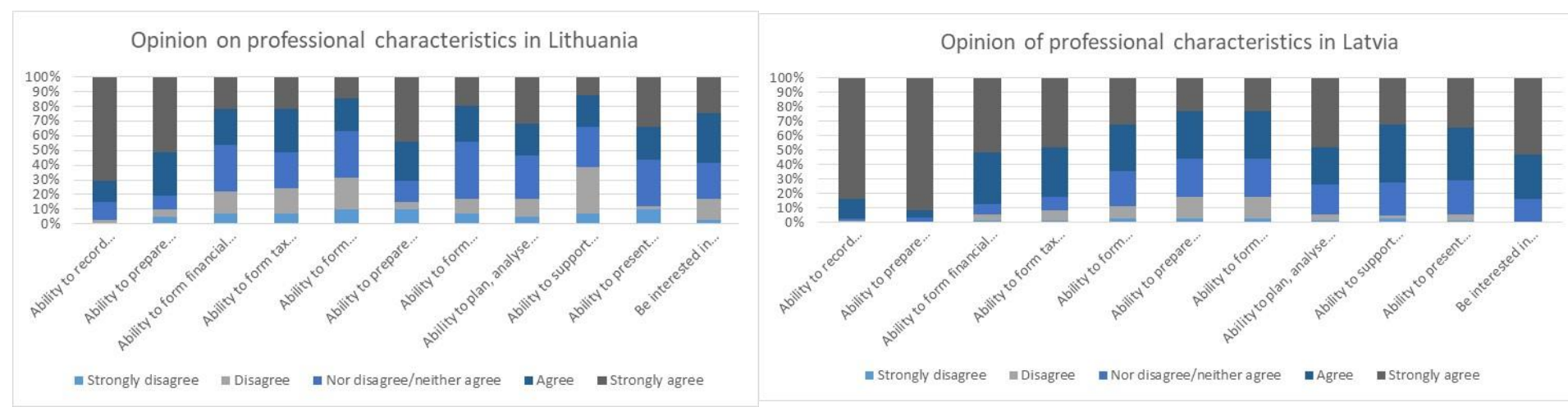

Fig. 8. Characteristics of accountant profession of professional sphere in Lithuania and Latvia, \%

Source: compiled by authors

Almost $71 \%$ Lithuanian respondents emphasized the ability to prepare different statements of different accounting types and fields (accordingly more than $56 \%$ of Latvian respondents). Approximately $72 \%$ of Latvian respondents agree or strongly agree with the importance of such abilities as ability to plan, analyse and evaluate company's performance, ability to support internal control system, ability to present analytical results, identify problems and propose alternatives to problem solving and only around $53 \%$ of Lithuanian respondents have the same opinion (opinion on ability to support internal control system even less $-34 \%$ ). Besides, Latvian respondents pay more attention to the ability to form management accounting policy: almost $65 \%$ strongly agree or agree that the characteristic is necessary for the accountant profession, more than $24 \%$ - have neutral opinion, 


\section{ENTREPRENEURSHIP AND SUSTAINABILITY ISSUES}

ISSN 2345-0282 (online) http://jssidoi.org/jesi/

2020 Volume 7 Number 4 (June)

http://doi.org/10.9770/jesi.2020.7.4(20)

and almost $12 \%$ - disagree or strongly disagree as opinion of Lithuanian respondents was distributed by one third accordingly.

Respondents of both countries have a rather similar opinion on characteristics of social sphere: from more than $75 \%$ to $90 \%$ of respondents agree or strongly agree with necessity of such abilities as ability to communicate with colleagues and persons from other institutions, ability to cooperate with colleagues and persons from other institutions, ability to work in team. Respondents in open questions also emphasized the ability to communicate, loyalty to the client, ability to predict the impact of legislation changes, ability to understand the processes of the company, the company as a whole.

Age of employees and their gross salaries are presented in Fig. 9, which shows, that age of employees, who work in outsourcing accounting companies is higher in Latvia: more than $47 \%$ of employees are younger than 30 years old in Lithuania and almost $24 \%$ - in Latvia, more than $36 \%$ employees are under the age of 30 - 50 years in Lithuania and almost $56 \%$ - in Latvia.

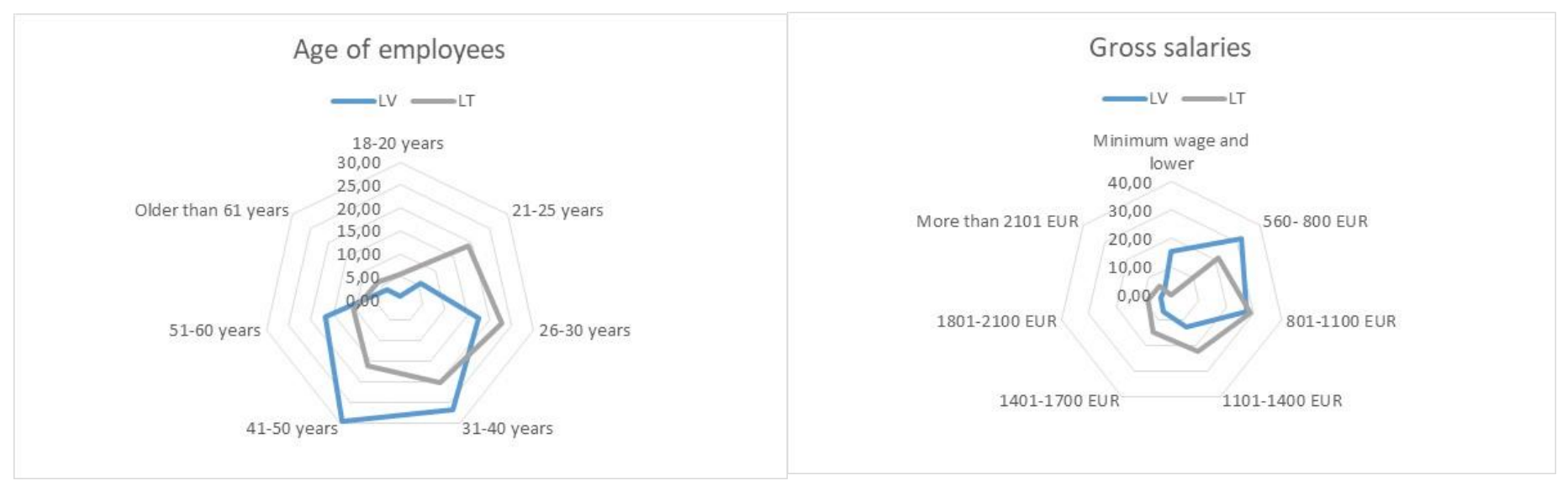

Fig. 9. Age of employees and gross salaries in Lithuanian and Latvian outsourcing accounting companies, \%

Source: compiled by authors

The value of gross salaries is higher in Lithuanian companies: almost $75 \%$ of employees in Latvia earn a gross salary of below 1100 Eur, in Lithuania - $50 \%$. Lithuanian companies didn't indicate any employees, who earn minimum wage or lower. Besides, in Lithuanian companies almost $45 \%$ of employees earn $1101-2100$ Eur salaries and more than $5 \%$ - earn more than 2101 Eur as in Latvia the numbers are accordingly almost $23 \%$ and almost $3 \%$. Most of employees work part time: more than $76 \%$ in Lithuanian companies and part time or part and full time - almost $65 \%$ in Latvian companies.

\section{Conclusions}

The accounting profession will face significant changes in the next three decades, and professional organizations, their members, educational institutions as well as accounting outsourcing companies will have to take action and respond.

The outsourcing accounting takes rather significant place in Lithuania and Latvia. Last few years more and more micro and small companies had started using outsourcing accounting instead of hiring employees. IFAC survey results show that challenges for accounting outsourcing are attracting new clients, keeping up with the new regulations and standards and experiencing pressure to lower fees. In the time tendency of over the next five 


\section{ENTREPRENEURSHIP AND SUSTAINABILITY ISSUES}

ISSN 2345-0282 (online) http://jssidoi.org/jesi/

2020 Volume 7 Number 4 (June)

http://doi.org/10.9770/jesi.2020.7.4(20)

years' regulatory environment was continued to be viewed as the most impactful, as well as technological development and capability to adapt to new client needs.

For evaluation of challenges of outsourcing accounting in Latvia and Lithuania the survey was conducted. The analysis results show that most of the accounting outsourcing companies have one owner, who is a self-employed accountant, and 2-5 owners with staff in Latvia and Lithuania. In both countries more than half of analysed companies had been performing for more than 9 years as well as most of the companies are micro. Research results show that in both countries the types of activity of companies, who purchase accounting services are sufficiently similar and do not differ more than 5 percentage points. Lithuanian companies provide accounting services for smaller companies than Latvian.

Accounting outsourcing companies face more challenges by attracting new customers in Lithuania than in Latvia, although in average, the research results refer to the results of the International Federation of Accountants Global SMP 2016 survey. Respondents in both countries aren't of the opinion that the rising costs is a significant challenge. However, opinions on the statement for keeping up with new regulations and standards is a challenge, differentiate: three fourths of Latvian respondents strongly agree or agree with the challenge, as one fourth of Lithuanian respondents - strongly disagree or disagree. Although differentiating from competition is more of a significant challenge for Lithuanian outsourcing accounting companies. Experiencing pressure to lower fees is evaluated at a rather similar level in both countries and around one fourth of respondents in both countries strongly disagree or disagree with the statement, although $63 \%$ of Lithuanian companies strongly agree or agree with the challenge (Latvian - $44 \%$ ). Almost half of Latvian companies don't perceive a challenge in managing cash flow and late payments as in Lithuania this part makes around $40 \%$. More than half of respondents in both countries strongly disagree or disagree with the challenge of retaining existing customers as well as the challenge of serving customers, who are operating internationally. Succession planning is significantly more of a challenge for Latvian accounting outsourcing companies, although more challenges with the personnel and staffing issues have Lithuanian companies (the difference of opinions doesn't exceed 15 percentage points). Both countries have a quite similar view on the challenge of technology developments: around one third of respondents of both countries strongly disagree or disagree with the statement.

Accounting outsourcing companies have quite the same view on characteristics of accountant profession in Latvia and Lithuania, although some differences may be distinguished. Research results show that respondents in both countries agree with around 5 percentage points difference, that accountant profession has to have such characteristics as accuracy, analytical skills and logical thinking, integrity, ability to resist work routine, ability to resist stress and pressure, ability to learn, responsibility. And $70 \%$ and more of respondents of both countries agree or strongly agree with the characteristics of personal sphere as ability to independently and continuously learn, ability to gather, process, analyse and critically evaluate data, and decision-making. However, $82 \%$ of Latvian respondents strongly agree or agree, that independence is an important ability for accountant profession but only $56 \%$ of Lithuanian respondents have the same opinion, as well as characteristics of management ability, opinions of respondents distributed accordingly by $53 \%(\mathrm{LV})$ and $20 \%$ (LT). Around $62 \%$ of Latvian respondents and $54 \%$ of Lithuanian respondents strongly agree or agree, that risk taking is an important characteristic for the accountant profession. The most interesting result is the evaluation of characteristic of creativity - only $44 \%$ of Lithuanian respondents and $58 \%$ of Latvian respondents strongly agree or agree with the necessity of such ability for accountant profession. Creativity is the most valued characteristic to a person of any profession, therefore such results may be contradictory evaluated. Analysis of the characteristics of professional sphere results show that more than $80 \%$ of respondents of both countries agree only on ability to record economic transaction to accounting documents and registers, and ability to prepare financial statements. Latvian respondents almost twice more than Lithuanian respondents value more such abilities as to form financial accounting policy, ability to form tax accounting policy and ability to support internal control system. Although almost $71 \%$ of Lithuanian respondents emphasized the ability to prepare different statements of 


\section{ENTREPRENEURSHIP AND SUSTAINABILITY ISSUES}

ISSN 2345-0282 (online) http://jssidoi.org/jesi/

2020 Volume 7 Number 4 (June)

http://doi.org/10.9770/jesi.2020.7.4(20)

different accounting types and spheres $(56 \% \mathrm{LV}), 56-84 \%$ of Latvian respondents - ability to form information system of the company, the ability to plan, analyse and evaluate company's performance, the ability to present analytical results, identify problems and propose alternatives to problem solving, be interested in innovations. Latvian residents pay more attention to ability to form management accounting policy. Respondents of both countries have quite similar opinion on characteristics of social sphere.

Research results show that the level of age of employees of outsourcing accounting companies is higher in Latvia. However, the value of gross salaries is higher in Lithuanian companies. Most of employees work part time in both countries.

Further research may be conducted in time perspective for an evaluation of the development of analysed aspects as well as expanding the research to other countries.

\section{References}

Bagieńska, A. 2016. The demand for professional knowledge as a key factor of the development of outsourcing of financial and accounting services in Poland, Business, Management and Education, 14(1), 19-33. https://journals.vgtu.lt/index.php/BME/article/view/2147. https://doi.org/10.3846/bme.2016.313

Bartkus, E.V., Mickaitis, A. 2009. Išorinių išteklių nuomos smulkiajame versle neigimo empirinis tyrimas [Empirical Research Abnegation of Outsourcing in Small Business]. Ekonomika ir vadyba [Economics \& Management], 14, 661-667. http://etalpykla.lituanistikadb.lt/fedora/objects/LT-LDB-0001:J.04 2009 1367168406504/datastreams/DS.002.0.01.ARTIC/content

Bruna, I., Senkus, K., Subaciene, R., Sneidere, R. 2017. Evaluation of Perception of the Accountant's Role at the Enterprise in Latvia and Lithuania. European Research Studies Journal, 20(3A), 143-163.

Employment rate. 2020. Eurostat database. Retrieved from https://ec.europa.eu/eurostat/databrowser/view/t2020 10/default/table?lang=en European Commission. 2019. European Commission Regulated Professions. Accountant profession. Retrieved from http://ec.europa.eu/growth/tools-databases/regprof/index.cfm

Gross domestic $\quad$ product. $2020 . \quad$ Eurostat $\quad$ database. $\quad$ Retieved https://ec.europa.eu/eurostat/tgm/table.do?tab=table\&init=1\&language=en \&pcode=teina011\&plugin=1

Hood D. 2018. The profession's biggest challenges. Retrieved from: https://www.accountingtoday.com/news/the-accounting-professionsbiggest-challenges

IFAC Global SMP Survey: 2016 Results. 2017, March. 2017. Retrieved from: https://www.ifac.org/system/files/publications/files/2016IFAC-Global-SMP-Survey.pdf

IFAC Global SMP Survey: 2016 Summary. 2017 March. 2017. Retrieved from: https://www.ifac.org/knowledge-gateway/contributingglobal-economy/publications/2016-ifac-global-smp-survey-report-summary

Islam, M.A. 2017. Future of Accounting Profession: Three Major Changes and Implications for Teaching and Research. Retrieved: from: https://www.ifac.org/global-knowledge-gateway/business-reporting/discussion/future-accounting-profession-three-major

Krell E. 2018. Finance and Accounting Outsourcing Assessing and Planning for Success. Chartered Professional Accountants of Canada. p.19.

Kutuzov M., Kotsiuba, Y. 2015. Accounting Outsourcing in Ukraine: Use, Problems and Prospects, Економічний часопис Східноєвропейського національного університету імені Лесі Українки [Accounting, Analysis, Statistics, Mathematical Methods and Information Technolog], 1(1) https://echas.eenu.edu.ua/index.php/echas/article/view/285, https://doi.org/10.29038/2411-4014-2015-01-83$\underline{87}$

Law on the Prevention of Money Laundering and Terrorism and Proliferation Financing of the Republic of Latvia 17.07.2008. 2019. Retrieved from: https://likumi.lv/ta/en/en/id/178987-law-on-the-prevention-of-money-laundering-and-terrorism-and-proliferation-financing 


\section{ENTREPRENEURSHIP AND SUSTAINABILITY ISSUES}

ISSN 2345-0282 (online) http://jssidoi.org/jesi/

2020 Volume 7 Number 4 (June)

http://doi.org/10.9770/jesi.2020.7.4(20)

Liakhovych H. I. 2017. Analysis of the Expediency of Switching to Accounting Outsourcing, Problemi Ekonomiki, 01 December 2017, 4, pp.392-397.

Lietuvos Respublikos Buhalterinès apskaitos ịstatymas [the Law on Accounting] No. IX-574, 6 November, 2001. Available on the Internet: https://www.e-tar.lt/portal/lt/legalAct/TAR.43178AA9832E/asr

Mackevičius, J., Subačienè, R. 2016. Lietuvos buhalterinès apskaitos Sistema: praeitis, dabartis, perspektyvos \{Lithuanian Accounting System: Past, Present and Prospects\}. [Monograph]. Vilnius: Academic Publishing.

Main GDP aggregates per capita. 2020. Eurostat database. Retrieved from https://appsso.eurostat.ec.europa.eu/nui/show.do?dataset=nama_10_pc\&lang=en

Millere I., Faitusa I., Grima S., Baldacchino P.J. A. 2018. Comparative Analysis of the Latvian and Maltese Regulatory and Professional Requirements for Accountants. New Challenges of Economic and Business Development - 2018: Productivity and Economic Growth: International Scientific Conference, May 10-12, 2018, Riga, Latvia: Proceedings Riga: University of Latvia, 463-473.

MindSpace. 2019, February 18. Five challenges facing accountants. Retrieved from https://www.accountex.co.uk/insight/2019/02/18/accountant-challenges/

Müller M.B. T. The Role of the Global Accountancy Profession in Addressing 21st Century Public Sector Challenges. IFAC. 2019, September 2, Retrieved from: https://www.ifac.org/knowledge-gateway/business-reporting/discussion/role-global-accountancy-profession$\underline{\text { addressing-21st }}$

Mwangi, G.M., Mutiso, A., Mungai, D. 2018. Assessing the Influence of Accounting Outsourcing on Financial Performance of Small and Medium Enterprises in Thika Subcounty, Kenya, Management and Economics Research Journal, 4, 148-155. https://doi.org/10.18639/MERJ.2018.04.655595

Popovici, N., Moraru. C. 2018. Outsourcing Management: Outsourcing Services Worldwide and in Romania. “Ovidius” University Annals, Economic Sciences Series. Volume XVIII, Issue 1/2018.

Stolowy, H. \&, Ding, Y. 2017. Financial Accounting and Reporting: a Global Perspective. 5th Edition. Hampshire, United Kingdom, Cengage Learning EMEA, p. 660.

Trading economics. 2020. Retrieved from https://tradingeconomics.com/latvia/indicators and https://tradingeconomics.com/lithuania/indicators

Dr. Ivita FAITUŠA is Assistant Professor at the Department of Finance and Accunting, Faculty of Business, Management and Economics, Riga, Latvia. Research interests: financial accounting and internal audit, analysis of activity of enterprises.

ORCID ID: orcid.org/0000-0003-4080-9499

Dr. Rasa SUBAČIENĖ is Professor at the Department of Accounting and Audit, Faculty of Economics and Business Administration, Vilnius University, Lithuania. Research interests: financial accounting, management accounting, analysis of activity of enterprises.

ORCID ID: orcid.org/0000-0001-6559-8478

Dr. Aida MAČERINSKIENÉ is Dean of the Faculty of Economics and Business Administration, Vilnius University, Professor in the Business Department. Scientific interests: tourism management, strategic planning, international project management, consumer behaviour. ORCID ID: orcid.org/0000-0002-0137-9388

Copyright (C) 2020 by author(s) and VsI Entrepreneurship and Sustainability Center

This work is licensed under the Creative Commons Attribution International License (CC BY).

http://creativecommons.org/licenses/by/4.0/

(c) (i) Open Access 